\title{
Pengaruh Tehnologi Digital, Terhadap Motivasi Belajar Peserta Didik
}

\author{
Muhasim \\ Palapa Nusantara Lombok-NTB \\ mhmsaidah@gmail.com
}

\begin{abstract}
Abstrak: Perkembangan tehnologi digital merupakan hasil rekayasa akal, pikiran dan kecerdasan manusia, yang tercermin dalam kemajuan ilmu pengetahuan, selanjutnya memberikan manfaat dalam segala aspek kehidupan manusia. Dalam perkembangan komunikasi manusia telah berhasil membawa kemajuan yang sangat pesat, dari perubahan komunikasi secara manual menjadi analog, dimana tehnologi digital, telah memberikan kemudahan dalam berkomunikasi secara cepat, tanpa dibatas jarak, ruang dan waktu melalui Internet. Berdasarkan data pengguna Internet di Indonesia 2016 sebanyak 132,7 juta orang dari jumlah penduduk Indonesia sebanyak 256,2 juta orang, tentu tahun 2017 ini jauh lebih pesat perlkembangannya. Dari hasil survei oleh Asosiasi Penyelenggara Jaringan Internet ( APJII ) ini, mengungkapkan bahwa rata-rata pengakses Internet di Indonesia 67,2 juta orang atau 50,7 persen, mengakses melalui prangkat genggam dan computer. Di Nusa Tenggara Barat sebanyak 3,3 juta atau 64 persen. Dari sejumlah pengguna internet tersebut 80 persen diantaranya berusia remaja 15 19 tahun, artinya usia ini masih tercatat sebagai peserta didik. Oleh karena itu tujuan tulisan ini adalah untuk mengetahui bagaimana manfaat tehnologi digital terhadap motivasi peserta didik. Metode yang digunakan dalam pembahasan adalah deskriptif kualitatitf. Sebagai bahan analisisdilengkapi data dan informasi hasil pengamatan, dokumen definisi-definisi yang diperoleh dari bukubuku yang ditulis oleh para ahli dan naskah-naskah melalui media sosial atau Internet. Hasil pembahasan diperoleh pengaruh positif tehnologi digital terhadap motivasi belajar peserta didik. Dengan tetap diarahkan mengantisipasi pengaruh negatif yang ditimbulkan yang dapat mengganggu moral, perilaku dan justru menjadi ancaman motivasi belajar peserta didik. Oleh karena harus diberikan energi Iman, kedisiplinan secara berkesinambungan, agar dapat bersikap positif memanfaatkan peluang tehnolog digital guna meningkatkan motivasi belajar peserta didik.
\end{abstract}

Kata Kunci : Tehnologi digital, Motivasi belajar, Peserta didik .

Palapa: Jurnal Studi Keislaman dan Ilmu Pendidikan

Volume 5, Nomor 2, November 2017; p-ISSN 2338-2325; e-ISSN 2540-9697; 53-77 
Abstract: The development of digital technologies is the result of engineering intellect, mind and human intelligence, which is reflected in the advancement of science, and provides benefits in all aspects of human life. In the development of human communication has managedto bring avery rapid progression, from communication tomanual ly change into analog, digital, where technology has provided ease in communicating quickly, without a limited distance, space and time through the Internet. Based on the data of Internet users in Indonesia 2016 as much as 132.7 million people from a total population of Indonesia as much as 256.2 million people, certainly the year 2017 is much more rapid development. From the results of a survey by the Association of organizers of Internet network, revealed that, on average, through the Internet in Indonesia 67.2 million or 50.7 percent, to access via mobile devices and the computer. In West Nusa Tenggara as many as 3.3 million or 64 percent. The number of internet users from 80 per cent of whom are aged 15-19 years, meaning the teen age is still recorded as learners. Therefore the purpose of this paper is to find out how digital technology benefits against the motivation of learners. The method used is descriptive qualitative studies. As the analysis of data and information furnished observations, document definitions obtained from books written by experts and scripts through social media or the Internet. Discussion of the results obtained positive influence motivation towards learning digital technology learners. With a fixed geared to anticipate the negative influence posed that can disrupt moral behavior, and thus a threat motivation learning learners. Because energy must be given Faith, discipline on an ongoing basis, in order to take advantage of positive tehnolog digital to enhance learning motivation of learners.

Keywords: Digital technology, Motivation of learning, Learners

\section{Pedahuluan}

Revolusi Industri di Inggris mampu merubah kehidupan masyarakat, dari manual menuju penggunaan tehnologi digital. Tehnologi digital seiring perkembangan ilmu pengetahuan dan tehnologi yang sangat pesat, sehingga zaman ini menggunakan tehnologi digital sebagai alat bantu. Karakteristik era ini, informasi dapat diperoleh sangat cepat, secepat cahaya,dunia ini seolah-olah menjadi sangat sempit tanpa ada batas jarak dan waktu .Sudah tidak asing lagi perkembangan 
tehnologi digital, sehingga melalui perangkat yang kita miliki, kita dapat melakukan hubungan yang sangat cepat, mencari bahan ajar sangat mudah baik melalui internet dan dengan menggunakan Email bisa berkirim surat elektronik, yang bisa dilakukan bukan saja melalui warnet namun melalui media digital hand phon. Hand phon ( HP) tidak lagi merupakan barang mewah, dan dimiliki orang kota, tetapi sampai dipelosok kampungpun, pengusaha atau birokrat, boleh dikatakan sudah menjadi kebutuhan bagi setiap orang dari orang dewasa dan remaja yang masih menjadi peserta didik.

Pengguna tehnologi digital seperti Internet di Indonesia 2016 sebanyak 132,7 juta orang dari jumlah penduduk Indonesia sebanyak 256,2 juta orang. Dari sejumlah itu 80 persen diantaranya berusia remaja 15-19 tahun. Data survei yang dilakukan oleh Asosiasi Penyelenggara Jaringan Internet (APJII) ini, juga mengungkapkan bahwa rata-rata pengakses Internet di Indonesia 67,2 juta orang atau 50,7 persen mengakses melalui prangkat genggam dan computer. Dan tercatat dipulau jawa tebesar sekitar 86,3 juta orang atau 65 persen dari angka total pengguna internet. Di NTB sebanyak 3,3 juta atau 64 persen dari jumlah penduduk. ${ }^{1}$ Jumlah penduduk 2014 sebanyak 4,702 jutaorang, artinya yang tidak menggunakan atau termasuk pengguna pasif sebesar 1.699 juta orang. Jika kita cermati pengguna dari jumlah remaja sebesar 80 persen dari 64 persen, maka yang tidak menggunakan, termasuk anak-anak dan orang jompo. Berdasarkan data di atas, sebenarnya secara tidak sadar sebagian besar dari anggota masyarakat dan remaja, setiap saat sudah tidak terpisahkan dengan media digital, dan ini sebuah bukti bahwa kita sekarang ini sudah berada pada revolusi digital. Menurut pendekatan ilmu pengetahuan memberikan gambarkan bahwa kita dan remaja yang masih menjadi peserta didik harus mampu mengikuti perkembangan ilmu pengetahuan dan tehnologi digital. Munculnya tehnologi digital sekitar tahun 1980 an, yang ditandai dengan perubahan tehnologi mekanik elektronik analog - ketehnologi elektronik digital.

Media aliansi Florida mendefinisikan media digital sebagai konvergensi kreatif seni digital, Ilmu pengetahuan, tehnologi dan bisnis untuk ekspresi manusia, komunikasi,

1 Tekno. Kompas.com (diakses 3 Agustus 2017 ). 
interaksi sosial, dan pendidikan. Tehnologi digital penggunaannyapun tidak sesulit seperti alat-alat yang masih mengunakan sistem manual. Dengan tehnologi digital, mengerjakan sesuatu dengan cepat, mudah dan praktis, tanpa banyak menguras tenaga. ${ }^{2}$

Terdapat beberapa kecanggihan tehnologi digital seperti mudah bekerja, karena beroperas secara otomatis, cepat, berkualitas, efektif, effisien, mudah mentransfer data dan informasi ke media elektronik lain. Dan banyak lagi kecanggihan-kecanggihan dari tehnologi digital ini yang dapat diambil manfaatnya untuk aktivitas manusia. Seperti Internet misalnya, kita bisa berhubungan secara online, sehingga manusia seolah-olah berada pada dunia yang sempit dengan jangkauan semakin luas, karena dirasakan lebih mudah, cepat dan dinamis menerima informasi serta berkomunikasi. Orang bisa menerima informasi dan berkomunikasi dengan pihak lain dari belahan dunia lain yang sangat jauh dalam hitungan detik, dengan jumlah yang sangat banyak dan beragam. Internet dengan sistem online, secara revoluisoner telah mengubah cara manusia berinteraksi baik secara individu maupun secara bersama, dalam dunia ekonomi di berbagai belahan dunia.

Tehnologi digital bukan merupakan hal yang baru dan datang secara tiba-tiba, tetapi sudah berproses sejak puluhan tahun 80an, sehingga sampai abad 21 sekarang ini, disebut era digital. Pada era ini penggunaan tehnologi digital sudah menjadi kebutuhan, bukan saja orang dewasa, tetapi juga remaja, bahkan anak dibawah umur sudah mengenal namanya Hand phon ( HP ) androit. Menggunakan perangkat digital dengan menggunakan media Google, Yahoo,bloog, email, kita dapat melihat jendela dunia. Tenaga kependidikan yang berkualifikasi sebagai guru, dosen, konselor, pamong belajar, widyaiswara, tutor, instruktur, fasilitator, dan sebutan lain yang sesuai dengan kekhususannya, dan peserta didik, dengan sangatmudah mencarikebutuhan bahan ajar yang mereka butuhkan.

Di abad ke 21 ini, tehnologi digital menjadi semakin penting, dan pemicu motivasi peserta didik, sehingga mereka memiliki keterampilan belajar dan berinovasi.Keterampilan menggunakan tehnologi digital membantu lebih cepat mendapatkaninformasi serta meningkatkan life skills sebagai modal bekerja, dan

2 http// sugikshare.blogspot.com (diakses 20 September 2017 ). 
pendidik dengan mudah mengembangkan bahan belajar. Tehnologi digital menjadi kebutuhan dunia pendidikan sekarang ini, terbukti sudah diadaptasi oleh Kementerian Pendidikan dan Kebudayaan Republik Indonesia untuk mengembangkan kurikulum baru dan sistem online serta mengembangkan pendidikan menuju Indonesia Kreatif tahun 2045. Adaptasi dilakukan untuk mencapai kesesuaian konsep dengan kapasitas peserta didik dan kompetensi pendidik dan tenaga kependidikannya. ${ }^{3}$

Bagaimana Indonesia sebagai Negara berkembang memanfaatkan tehnologi digital seperti Internet melalui warnet maupun di HP, dengan berbagai fasilitas seperti bloog, Email dan sebagainya. Tehnologi digital dapat mempermudah segala aktivitas hidup manusia serta mengases berbagai informasi diberbagai aspek kehidupan manusia termasuk aspek pendidikan.Oleh karena itu tujuan tulisan ini adalah untuk mengetahui bagaimana manfaat tehnologi digital terhadap motivasi belajar peserta didik.Metode yang digunakan dalam pembahasan adalah metode deskriptif kualitatitf. Menurut H.M.Burhan Bungin, mengatakan bahwa penelitian kualitatif, lebih banyak dipengaruhi oleh pandangan -pandangan deduktif kualitatif. ${ }^{4}$ Pendektan kualitatif deskriptif tidak sepenuhnya kualitatif, namun sebagai sebuah kebisaan dan berusaha mendekatikualitatif. Sebagai bahan analisis teoridilengkapi data, informasi hasil pengamatan, dokumen definisi-definisi yang diperoleh dari buku-buku yang ditulis oleh para ahli dan naskah-naskah melalui media sosial atau Internet.

\section{Landasan Teori}

Teknologi secaraharfiah berasaldari kata Perancis yaitu La Teknique yang berarti suatu konsep yang dibuat sebagai upaya proses pewujudan secara rasional. pemahaman rasional disini ialah suatu proses yang dapat dilakukan secara berulangulang atau berkali-kali. Teknologi merupakanmodifikasi manusia yang dikembangkan dari teknologi yang sudah ada secara alami yang kemudian diproses kedalam media sesuai kebutuhannya masing-masing. ${ }^{5}$

3 Kuntari Eri Murti, Artikel Kurikulum pendidikan 2013.

4 H.M. Burhan Bungin, Metodologi Penelitian Kualitatif, Penerbit Grapindo, Jakarta, tahun 2001, 23.

5 Wikipedia bahasa Indonesia. 
Digital suatu konsep yang didasari dari 0 dan 1 yang mendeskripsikan antara off dan on. Proses penjabaran ini didasari menggunakan logika algoritma. ${ }^{6}$ Digital dapat melakukan semua proses secara bersamaan seperti misalnya proses produksi, distribusi dan konsumsi yang kesemuanya dapat dilakukan dalam satu sistem. Jika dalam perspektif komunikasinya digital merupakan komunikasi yang disaranai oleh media (bermediasi), maka media komunikasi tersebut dapat dilakukan dengan menggunakan media telekomunikasi atau internet.

Teknologi digital yaitu teknologi yang dioperasikan dengan menggunakan sistem komputerisasi, sistem tersebut didasari dari bentuk informasi sebagai nilai numeris 0 dan 1 yang mengidentifikasikan tombol hidup dan mati.Teknologi digital juga dapat dikatakan teknologi nirkabel, maksudnya adalah teknologi ini memanfaatkan signal sebagai sarana penghubung kepada medianya sebagai penyampai pesan. Sinyal digital mempunyai keistimewaan tersendiri bahwa kecepatan yang di kirimkan oleh sinyal tersebut melebihi kecepatan cahaya yang mana sistem ini tidak ditemukan dalam teknologi analog.Teknologi digital dalam perspektif komunikasi merupakan sistem penyampaian yang efisien, komunikasi menjadi lebih dinamis tanpa terhalang oleh ruang dan waktu. Contoh manfaat teknologi digital dalam kehidupan bermasyarakat dapat dilihat dari komunikasi yang dilakukan dengan menggunakan perantara internet, ada berbagai aplikasi internet yang menyediakan sarana video call atau chatting dalam menciptakan terjalinnya komunikasi dua arah. Namun pada hakikatnya komunikasi menggunakan teknologi digital bermuara pada penyampaian atau hasil yang diterima secara analog, perlu diketahui bahwa teknologi digital merupakan jembatan dalam mengirimkan data baik visual atau tulisan melalui gelombang sinyal, namun pada akhirnya hasil yang diterima oleh si penerima adalah analog, karena hasilnya dapat kita terima oleh panca indera kita.

Motivasi menurut Stanley Vance (1982) pada hakikatnya adalah perasaan, atau keinginan seseorang yang berada dan bekerja pada kondisi tertentu untuk melaksanakan tindakan-tindakan yang menguntungkan dilihat dari perspektif pribadi. Dalam hubungan dengan itu Robert Dubin (1985), mengatakan motivasi sebagai

6 Wikipedia bahasa Indonesia (Diakses 29 Septembee 2017) 
kekuatan kompleks yang membuat seseorang berkeinginan memulai dan menjaga kondisi kerja dalam organisasi. ${ }^{7}$

Motivasi itu merupakan proses yang membutuhkan tenaga, disiplin waktu, ketekunan, sehingga untuk menjalankan motivasi perlu energi. Dalam hal ini kita merujuk pendapat Neil Lebovits, mengemukakan bahwa motivasi merupakan proses dimana seseorang diberi energi, diarahkan, disiplin dan berkelanjutan menuju tercapainya suatu tujuan.

a. Elemen Energi, adalah ukuran dan intentitas atau dorongan. Seseorang yang termotivasi menunjukkan usaha dan bekerja keras.

b. Elemen diarahkan, Usaha tingkat tinggi perlu diarahkan pada cara yang dapat membantu organisasi mencapai tujuan.

c. Elemen ketekunan, karyawan diharapkan tetap tekun dalam usahanya untuk mencapai tujuan tersebut. ${ }^{8}$

Pengertian belajar menurut Morgan,adalah setiap perubahan yang relatif menetap dalam tingkah laku yang terjadi sebagai suatu hasil dari latihan atau pengalaman (Wisnubrata, 1983:3). Sedangkan menurut Moh. Surya (1981:32), belajar adalah suatu proses usaha yang dilakukan individu untuk memperoleh suatu perubahan tingkah laku yang baru keseluruhan, sebagai hasil pengalaman individu itu sendiri dalam interaksinya dengan lingkungan. Dari uraian yang tersebut di atas, dapat disimpulkan bahwa pada prinsipnya, belajar adalahperubahan dari diri seseorang. Sedangkan pengertian motivasi belajar adalah keseluruhan daya penggerak baik dari dalam diri maupun dari luar siswa (dengan menciptakan serangkaian usaha untuk menyediakan kondisi-kondisi tertentu) yang menjamin kelangsungan dan memberikan arah pada kegiatan belajar, sehingga tujuan yang dikehendaki oleh subjek belajar itu dapat tercapai. ${ }^{9}$

Peserta didik merupakan bagian dalam sistem pendidikan sebagai objek atau bahan mentah dalam proses transformasi pendidikan. Tanpa adanya peserta didik, keberadaan sistem pendidikan tidak akan berjalan. Karena kedua faktor antara pendidik dan peserta didik merupakan komponen paling utama dalam suatu sistem

7 http:/ / arifakbarmuhamad.wordpres.com (diakses 2 Agustus 2017 ).

8 Stephen P. Robbins, Manajemen, Penerbit Erlangga, Jakarta, tahun 2010, 109.

9 http://belajarpsikologi.com/pengertian-motivasi-belajar/ 
pendidikan.Secara bahasa peserta didik adalah orang yang sedang berada pada fase pertumbuhan dan perkembangan baik secara fisik maupun psikis, pertumbuhan dan perkembangan merupakan ciri dari seseorang peserta didik yang perlu bimbingan dari seorang pendidik.Pertumbuhan yang menyangkut fisik, perkembangan menyangkut psikis. Abdul Mujib mengatakan berpijak pada paradigma "belajar sepanjang masa", maka istilah yang lebih tepat untuk menyebut individu yang menuntut ilmu adalah peserta didik bukan anak didik. ${ }^{10}$ Peserta didik mengandung pengertian individu yang sedang menuntut ilmu baik dari tingkat Sekolah Dasar, Sekolah Menengah Pertama, Sekoah Menengah Atas dan Perguruan Tinggi, maupun yang sedang mencari ilmu pada lembaga non formal. Menurut UU RI No 20 Tahun 2013, tentang Sindiknas, peserta didik adalah anggota masyarakat yang berusaha mengembangkan potensi diri melalui proses pembelajaran yang tersedia pada jalur, jenjang, dan jenis pendidikan tertentu. ${ }^{11}$

\section{Perkembangan Tehnologi Digital.}

Bertolak dari teori yang diuraikan dalam landasan teori dapat menjadi rujukan untuk mencermati unsur-unsur dari tehnologi digital, secara garis besarnya adalah merupakan hasilolah kecerdasan dan perkembangan ilmu pengetahuan manusia, selanjutnya diitegrasikan dengan aktivitas manusia, dan secara berkelanjutan akan memberikan input dalam perkembangan tehnologi dan ilmu pengetahuan secara berkesinambungan. Hasil olah kecerdasan mansia, merekayasa sinyal digital menghasilkan input keistimewaan tersendiri, sehingga dengan kecepatan tehnologi digital tersebut mengirimkan sinyal melebihi kecepatan cahaya, yang sistem ini tidak ditemukan dalam teknologi analog. Teknologi digital menghasilkan kecanggihan dalam perspektif komunikasi, dimana penyampaian pesan secara efisien, lebih dinamis tanpa terhalang oleh jarak, ruang dan waktu.

Teknologi adalah satu ciri yang mendefinisikan hakikat manusia yaitu bagian dari sejarahnya meliputi keseluruhan sejarah.Menurut kamus computer dan teknolgi informasi, definisi teknologi adalah penerapan keilmuan yang mempelajari dan mengembangkan kemampuan dari suatu rekayasa dengan langkah dan teknik tertentu

10 http://globallavebookx.blogspot.co.id/2015/03/pengertian-peserta-didik-menurut-ahli.html. 11 Sekretaris Negara Republik Indonesia, UU RI No:20 Tahun 2003, Tentang Sistem Pendidikan Nasional. 
dalam suatu bidang. ${ }^{12}$ Sedangkan menurut Djoyohadikusumo (1994, 222) berkaitan erat dengan sains (science) dan perekayasaan (engineering). Dengan kata lain, teknologi mengandung dua dimensi, yaitu science dan engineering yang saling berkaitan satu sama lainnya. Sains mengacu pada pemahaman kita tentang dunia nyata sekitar kita, artinya mengenai ciri-ciri dasar pada dimensi ruang, tentang materi dan energi dalam interaksinya satu terhadap lainnya.Teknologi adalah satu ciri yang mendefinisikan hakikat manusia yaitu bagian dari sejarahnya meliputi keseluruhan sejarah. $^{13}$

Makna Teknologi, menurut Capra $(2004,106)$ seperti makna 'sains', telah mengalami perubahan sepanjang sejarah. Teknologi, berasal dari literatur Yunani, yaitu technologia, yang diperoleh dari asal kata techne, bermakna wacana seni. Ketika istilah itu pertamakali digunakan dalam bahasa Inggris di abad ketujuh belas, maknanya adalah pembahasan sistematis atas 'seni terapan' atau pertukangan, dan berangsur-angsur artinya merujuk pada pertukangan itu sendiri Pada abad ke-20, maknanya diperluas untuk mencakup tidak hanya alat-alat dan mesin-mesin, tetapi juga metode dan teknik non-material, yang berarti suatu aplikasi sistematis pada teknik maupun metode. Sekarang sebagian besar definisi teknologi, lanjut Capra (2004, 107) menekankan hubungannya dengan sains. Ahli sosiologi Manuel Castells seperti dikutip Capra $(2004,107)$ mendefinisikan teknologi sebagai 'kumpulan alat, aturan dan prosedur yang merupakan penerapan pengetahuan ilmiah terhadap suatu pekerjaan tertentu dalam cara yang memungkinkan pengulangan. ${ }^{14}$

Teknologi informasi telah membuka mata dunia akan sebuah dunia baru, interaksi baru, market place baru, dan sebuah jaringan bisnis dunia yang tanpa batas. Disadari betul bahwa perkembangan teknologi yang disebut internet, telah mengubah pola interaksi masyarakat, yaitu; interaksi bisnis, ekonomi, sosial, dan budaya.Internet telah memberikan kontribusi yang demikian besar bagi masyarakat, perusahaan/ industri maupun pemerintah. Hadirnya Internet telah menunjang efektifitas dan efisiensi aktivitas hidup manusia, terutama peranannya sebagai sarana komunikasi,

12 http://www.total.or.id( diakses 15 September 2017 ).

13 http://ajidedim.wordpress.com (diakses 19 September 2017 ).

14 http://ajidedim.wordpress.com(diakses 20 September 2017 ). 
publikasi, serta sarana untuk mendapatkan berbagai informasi yang dibutuhkan oleh sebuah badan usaha dan bentuk badan usaha atau lembaga lainya. ${ }^{15}$

Teknologi Informasi adalah suatu teknologi yang digunakan untuk mengolah data, termasuk memproses, mendapatkan, menyusun, menyimpan, memanipulasi data dalam berbagai cara untuk menghasilkan informasi yang berkualitas, yaitu informasi yang relevan, akurat dan tepat waktu. Informasi tersebut digunakan untuk keperluan pribadi, bisnis, dan pemerintahan dan merupakan informasi yang strategis untuk pengambilan keputusan.Teknologi ini menggunakan seperangkat komputer untuk mengolah data, sistem jaringan untuk menghubungkan satu komputer dengan komputer yang lainnya sesuai dengan kebutuhan, dan teknologi telekomunikasi digunakan agar data dapat disebar dan diakses secara global.Peran yang dapat diberikan oleh aplikasi teknologi informasi ini adalah mendapatkan informasi untuk kehidupan pribadi seperti informasi tentang kesehatan, hobi, rekreasi, dan rohani. Kemudian untuk profesi seperti sains, teknologi, perdagangan, berita bisnis, dan asosiasiprofesi. Sarana kerjasama antarapribadi atau kelompok yang satu dengan pribadi atau kelompok yang lainnya tanpa mengenal batas jarak dan waktu, negara, ras, kelas ekonomi, ideologi atau faktor lainnya yang dapat menghambat bertukar pikiran. Pada saat ini perkembangan teknologi informasi (internet) telah merambah berbagai bidang dengan fasilitas elektronika-nya yaitu, e-life, e-commerce, egovernment, e-education, e-library, e-journal, e-medicine, e-laboratory, e-biodiversity, dan masih banyak yang lainnya.

Teknologi internet semakin berkembang, semakin cepat, tepat, akurat, kecil, murah, mudah, efektif dan efisien. Proses berkomunikasi pun memiliki ciri dan sifat yang seperti itu, khususnya efektif. Proses mengirimkan pesan dari Indonesia ke Kanada tidak usah menunggu hingga berminggu-minggu berkat e-mail. ${ }^{16}$ Dengan internet informasi yang diperlukan dapat diperoleh dengan sangat cepat, begitu pula kita dapat mengirimkan berikta dapat dilakukan dengan cepat, saat ini dikirim saat itu pula berita diterima.Bagi seseorang yang berkecimpung dalam dunia bisnis,

\footnotetext{
15 http://www.goechi.com ( diakses 17 September 2017 ).

16 http:/ / dictum4magz.wordpress.com/(diakses 20 September 2017 ).
} 
pengiklanan produk dapat dilakukan dengan cepat dan efisien serta dapat dilihat oleh orang sedunia.

Kecepatan dan ketepatan informasi sangat dimungkinkan oleh pemakaian media dengan teknologi yang tepat. Hingga perlu digarisbawahi di sini adalah berbicara komunikasi dan media maka kita juga akan membicarakan komunikasi. Media adalah teknologi dan teknologi adalah media. ${ }^{17}$ Teknologi digital dalam kehidupan bermasyarakat sekarang ini, secara nyata dapat dilihat berkembang dalam komunikasi sosial dengan menggunakan perantara internet, dengan berbagai programseperti video call atau chatting, email, beloog, facebook, twiter dsbanya dalam menciptkan terjalinnya komunikasi dua arah. Namun pada hakikatnya perkembangan komunikasi menggunakan teknologi digital, juga berakhirnya pada terciptnya output komunikasi secara analog.Fungsi teknologi digital menjadi jembatan dalam mengirimkan data baik visual atau tulisan melalui gelombang sinyal, dan menghasilkan output komunikasi analog, karena hasilnya dapat oleh panca indera mansia.

Perekembangan tehnologi digital ini mendorong penyebaran informasi yang demikian cepat, karenadengan mudahnya penyebaan informasi dari belahan dunia lain lingkungankehidupan disegala aspek kehidupan terus berubah. Hal itu berdampak positif kepada para guru dan peserta didik memperoleh materi ajar yang diperlukan. Perubahan itu terus bergulir semakin cepat, dan pasti mendatang pengaruh baik positif maupun negatif. Perubahan adalah fenomena kehidupan manusia yang berjalan secara terus menerus dengan kata lain perubahan itu sifatnya abadi sepanjang waktu. Perubahan tidak akan bisa dihentikan dengan cara apapun, justru semakin berupaya kita hentikan, akan semakin banyak dampak yang terjadi, ibarat penyakit kangker ganas, semakin berdampak komplikasi yang merugikan. Perubahan menuntut akal, pikiran dan kecerdasan manusia harus mampu mengambil manfaat positif, bagaimanapun bentuk perubahan, karena tidak mungkin dapat dibendung, ibarat pergantian hari, bulan, tahun dan abad.

Sekarang ini kita berada pada abad 21 disebut abad milenium ke tiga dalam kalender gregorian.Abad ini perubahan zaman meningkat secara dramatis, seiring

\footnotetext{
${ }^{17}$ http:/ / dictum4magz.wordpress.com( diakses 20 September 2017 ).
} 
dengan kemajuan tehnologi digital yang lazim disebut Globalisasi. Abad 21 baru berjalan kurang lebih 17 tahun, akan berakhir di tahun 2099, kurang lebih lagi 83 tahun. Kita belum bisa memprediksi perubahan apa yang akan terjadi, jika kita tidak mempersiapkan diri,maka perubahan zaman itu bukan saja akan menjadi tantangan tetapi bencana, oleh karena itu semua masyarakat dituntut, siap harus terus meningkatkan ilmu pengetahuan, kecerdasan dan skill, karena diprediksi tuntutan itu, paling signifikan merubah perilaku manusia menghadapi perubahan zaman.

Perubahan zaman diserta dengan perkembangan tehnologi digital sangat cepat mempngaruhi kehidupan manusia. Munculnya berbagai fasilitas tenologi digital, kita fasilitas Internet, seperti WWW (World Wide Web) yang paling banyak digunakan saat ini di samping email. Situs web adalah informasi yang dapat diakses oleh seluruh pengguna internet dari seluruh dunia dengan menggunakan program yang disebut Web Browser misalnya Netscape Navigator dan Microsoft Internet Explorer. Informasi yang ditempatkan dalam situs web itu dapat berupa tulisan, gambar, animasi, suara, dan video klip. Sebagai sarana komunikasi, sistus web tersebut berguna untuk mencari data, berita, mengikuti perkembangan ilmu pengetahuan baru, dan lain lain. Peserta didik (Mahasiswa) banyak mengunjungi web situs seperti friendster, detik, satuwanita, yahoo, CNN, Kompas dan sebagainya.

Walaupun ada banyak manfaat situs web, juga ada banyak masalah.Masalah yang paling besar adalah bahwa informasi yang disebarkan di internet tidak selalu benar. Hal ini terjadi karena situs web tidak harus memberikan informasi yang benar dan akurat, dan tidak ada tanggung jawab atas kebenaran informasi yang disebarluaskan. Masalah yang kedua adalah pornografi yang merupakan dampak negatif. Namun, pornografi itu tidak harus dicari dengan sengaja, bisa saja mendapatkan pornografi dengan pencarian data dan file musik mp3. Dari pengamatan yang mendalam, tiga puluh tiga persen dengan sengaja mencari pornografi di www, dan bukan hanya laki-laki tetapi juga perempuan. Walaupun demikian, kebanyakan adalah mahasiswa yang dengan sengaja mencari pornografi. Sedangkan, yang tidak dengan sengaja mendapatkan pornografi sebanyak lima puluh sembilan persen. ${ }^{18}$

18 winstarlink.com.” apakah Indonesia sudah siap dengan era digital “( diakses 20 Agustus 2017 ) 
Kemampuan tehnologi digital dapat mempengaruhi perilaku seseorang, secara tidak langsung mempengaruhi etika pergaulan, yang cendrung megikuti apa yang dilihat dalam media online yang kadang-kadang kurang cocok dengan budaya dan nilai-nilai kehidupan setempat. Pemanfaatan waktu, disiplin belajar, tersita oleh waktu kesibukan dengan bermain gim di Internet, menonton TV dan bermain facebook, kotak katik bloog, dan banyak lagi tayangan-tayangan di Internet yang dapat mengganggu disiplin belajar peserta didik. Oleh karena itu peran orang tua dalam mengawasi pemanfaatan internet di rumah, dengan mengatur waktu dan disiplin belajar yang terjadwal, agar peserta didik selain terhindar dari pengarauh negatif, juga dapat memanfaatkan waktu belajar dengan baik.Demikian halnya dengan peran duru di sekolah untuk mengawasi dan membimbing peserta didik, agar dapat memanfaatkan tehnologi digital sebagai media belajar, sehingga dapat bermanfaat secara positif dan dapat mencerdaskan dan memperkaya skill peserta didik sebagai bekal hidupnya setelah menyelesaikan pendidikannya.

Dengan berkembangnya ilmu pengetahuan dan teknologi pada zaman sekarang ini, Indonesia sebagai Negara berkembang dituntut untuk mengikuti arus globalisasi dunia. Masyarakat Indonesia dihadapkan dengan berbagai fasilitas yang selalu berkembang, salah satunya adalah perkembangan teknologi digital yang semakin mudah dijumpai.Perkembangan teknologi menghasilkan berbagai macam fasilitas, kualitas dan manfaat yang ditawarkan oleh teknologi informasi, yang tujuannya untuk memudahkan segala aktivitas hidup manusia dalam melakukan pekerjaan dan mengakses berbagai informasi. Dengan adanya kemajuan teknologi ini, akan membawa pengaruh yang cukup besar terhadap segala aspek kehidupan, mulai dari kegiatan perkantoran, hiburan, keagamaan dan pendidikan.

Mencermati pembahasan diatas sistem informasi merupakan seperangkat komponen yang saling berhubungan yang berfungsi mengumpulkan, memproses, menyimpan, dan mendistribusikan informasi untuk mendukung pembuatan keputusan dan pengawasan dalam organisasi. Sistem informasi merupakan suatu sistem yang berkaitan dengan pengumpulan, penyimpanan, dan pemprosesan data, baik yang dilakukan secara manual maupun dengan bantuan komputer untuk menghasilkan informasi yang berguna dalam pengambilan keputusan. Kaitannya dengan unsur mengumpulkan bahan ajar kalau kita berbicara dengan kebutuhan 
pembelajaran baik itu guru mupun peserta didik, memang sangat mudah, dengan hanya membuka "google. com", kita sudah bisa menemukan berbagai kebutuhan yang kita perlukan. Selanjutnya kita dapat memproses sesuai dengan desain pembelajaran yang diharuskan, menyimpan dalam computer dan membukanya kembali ketika dibutuhkan.

Secara teoritis demikian mudahnya dengan bantuan tehnologi digital, apa yang dibutuhkan oleh peserta didik dan guru dapat diperoleh dengan memanfaatkan tehnologi digital atau Internet. Ironisnnya bersamaan dengan itu tayangan yang bersifat kurang cocok dengan tata kehidupan peserta didik dalam pembelajaran, seperti film-film porno, atau tayangan film-film yang kurang layak disaksikan peserta didik juga terselipkan oleh orang-orang yang bermaksud merusak moral generasi pelnjut bangsa ini. Oleh karena itulah selama proses mengumpulkan, mendesain, menyimpan bahan ajar, harus tetap mendapat pengawasan oleh guru disekolah maupun orang tua dilingkungan keluarga.

Berkaitan dengan pendapat diatas, sistem teknologi digital, sumberdaya manusia termasuk peserta didik harus dipersiapkan untuk menerima perkembangan tehnologi digital serta memanfaatkannya dengan baik dan positif, sehingga investasi yang besar untuk pengadaan sistem teknologi informasi akan diimbangi pula dengan peningkatan kualitas pembelajaran melalui peningkatan motivasi belajar peserta didik.

\section{Motivasi Belajar Peserta Didik}

Motivasi diibaratkan sebagai energy yang membangkitkan minat, kemauan seseorang mau melaksanakan sesuatu aktivitas, baik atas kehendak dirinya atau atas kehendak orang lain, dengan tujuan yang diinginkan. Pengertian motivasi banyak dikaitkan oleh para ahli dengan aktivitasmanusia pada organisasi kantoran atau perusahaan dan pendidikan termasuk berhubungan motivasi belajar dengan peserta didik.Peserta didik dimaksudkan sebagaimana dikemukakan dalam landasan teori adalah peserta didik yang sedang mencari ilmu pada semua jenjang dan jenis pendidikan, baik formal maupu non formal. Menurut Abraham Maslow seorang psikolog, menyatakan bahwa dalam setiap orang terdapat sebuah hirarki dari lima kebutuhan: 
1. Kebutuhan fisiolgis (physiological needs), kebutuhan seseorang akan makan,minuman, tempat berteduh, seks, dan kebutuhan fisik lainnya.

2. Kebutuhan keamanan (safety needs). Kebutuhan seseorang akan kemanan dan Perlindungan dari kejahatan fisik dan emosional, serta jaminan bahwa kebutuhan fisik akan terus terpenuhi.

3. Kebutuhan sosial (social needs). Kebutuhan seseorang akan kasih sayang, rasamemiliki, memiliki,penerimaan dan persahabatan.

4. Kebutuhan pengargaan (esteem needs). Kebutuhan seseorang akanfactor-faktor Penghargaan internal, seperti harga diri, otonomi, dan prestasi serta factor-faktor penghargaan eksternal seperti status, pengakuan, dan perhatian.

5. Kebutuhan aktualisasi diri (self actualization needs). Kebutuhan seseorang akan Pertumbuhan, pencapaian potensi seseorang, dan pemenuhan diri, dorongan untuk mampu menjadi apa yang diinginkan. ${ }^{19}$

Pendapat Maslow danStanley Vance, Robert Dubin, Neil Lebovits, sebagaimana juga diuraikan dalam landasanteori dapat dijadikan rujukan untuk membahas motivasi peserta didik. Motivasi menurut pendapat para ahli menangkut kebutuhan hidup manusia, yang bersangkut paut dengan keinginan atau perasaan pribadi manusia. Tentu masing-masing orang mempunyai keinginan yang berbeda, juga merasakan bagaimana perasaan mereka masing-masing terhadap pemenuhan hajat hidup mereka. Tedapat seseorang yang berada pada tingkat layak hidup menurut pendapat mereka, dan marasa cukup puas dengan keadaan dan kondisi yang dirasakan, maka mereka memiliki motivasi tertentu dalam hidupnya. Sebaliknya terdapat seseorang yang merasakan keadaan yang selalu mempunyai motivasi untuk mencapai tingkat kehidupan sampai pada tingkat aktualisasi diri, tentu mereka akan terus termotivasi untuk mencapai tingkatan tersebut.

Perasaan tersebut cocok dengan pendapat Stanley Vance, pada hakikatnya motivasi adalah perasaan, atau keinginan seseorang yang berada dan bekerja pada kondisi tertentu untuk melaksanakan tindakan-tindakan yang menguntungkan dilihat dari perspektif pribadi.Keinginan yang demikian tinggi tersebut, maka motivasi sebagai kekuatan kompleks yang membuat seseorang berkeinginan memulai dan

${ }^{19}$ Opcit, H.M. Burhan Bungin, Metodologi Penelitian Kualitatif, Penerbit Grapindo, Jakarta, tahun $2001,23$. 
menjaga kondisi yang mereka inginkan. Kondisi yang mereka inginkan tidak dengan mudah dicapai, namun membutuhkan sebuah proses, hal ini kita bisa merujuk pendapat Neil Lebovits, mengemukakan bahwa motivasi merupakan proses dimana seseorang diberi energi, diarahkan, disiplin dan berkelanjutan menuju tercapainya suatu tujuan. Energi yang mendorong motivasi mereka untuk bekerja keras dan berusaha secara terus menerus, tekun dan disiplin, terhadap peserta didik bermakna belajar sepanjang masa guna mewujudkan tujuan yang diinginkan.

Pengertian belajar dapat dirujuk pendapat Morgan, Moh Surya, sebagaimana dikemukakan dalam landasan teori adalah setiap perubahan tingkah laku individu hasil dari proses belajar, baik sebagai hasil pengalaman individu itu sendiri dan dalam berinteraksi dengan lingkungan. Dari uraian di atas, apabila konsep tehnologi digital dan pembelajaran digabungkan, maka akan tercipta model pembelajaran multimedia. Model ini merupakan gabungan gambar, audio, video dan animasi digunakan dalam proses pembelajaran, sehingga proses pembelajaran akan berkembang dengan baik.

\section{Manfaat Tehnologi Digital Terhadap Motivasi Belajar Peserta Didik}

Dari uraian di atas, apabila konsep tehnologi dan pembelajaran digabungkan maka pembelajaran dapat diartikan sebagai pembelajaran yang berbasis tehnologi digital. Tehnologi digital bermanfaat terhadap perubahan perilaku manusia termasuk pendidikan dan peserta didik, didalam mencari, mengumpulkan, mendokumentasikan, mengolah dan mentransfer kembali bahan ajar sesuai kebutuhan. Meramu bahan ajar dalam proses pembelajaran dengan tehnologi digital dapat lebih menarik serta memberikan motivasi belajar, sebab meramu bahan ajar tidak monoton pada teks, tetapi dapat diramu lebih seni dan menarik karena digabungan gambar, audio, video dan animasi, sehingga dapat mempengaruhi perubahan perilaku belajar berkembang lebih baik.

Peseta didik di abad 21 sekarang ini yang dikenal dengan abad tehnologi modern, dengan segala pasilitas yang tersedia, dikenal sangat canggih mulai tahun 1980 an. "Sebut saja pemakaian komputer, hingga pemakaian tehnologi komunikasi seperti handphone kini sudah merayap sampai kepelosok des kita gunakan. Kemajuan tehnologi tersebut memberikan manfaat terhadap kerja manusia lebih 
efektif, efisiensi, mudah dan lebih cepat, sebaliknya bagi sumber daya manusia yang tidak mampu menggunakan tehnologi digital itu dengan baik dan benar, merubah kehidupan menjadi lebih buruk bin aneh. Kayak misalnya dengan adanya "Medsos", orang-orang jadi kayaknya tidak punya rahasia lagi dalam hidupnyai share dan dinikmatin sama orang banyak, makanya tidak heran kalau kejahatan penculikan anak, penipuan, terorisme, atau pembunuhan jadi lebih sering muncul”.

Proses pembelajaran harus terhindar dari pengaruh buruk kemauan tehnologi,sehingga diperlukan pembimbingan dan pengawasan kepada peserta didik baik oleh guru maupun orang tua, agar pengaruh positif dari kemajuan tehnologi digital ini dapat dapat bermanfaat. Pendidik dan peserta didik dalam proses pembelajaran, akan termotivasi menggunakan sebuah sistem teknologi digital apabila individu tersebut merasa memperoleh manfaat dari keberadaan sistem teknologi tersebut. Perkembangan sistem teknologi digital tidak dapat dipisahkan dengan kegiatan pembelajaran, tetapi hal itu bisa mempengaruh positif maupun negatif. Oleh sebab itu dibutuhkan latihan berpikir positif terhadap peserta didik agar kemajuan tehnologi digital ini dapat bermanafaat terhadap motivasi.

Pendapat Maslow dan Stanley, dapat dijadikan rujukan, dimana dikemukakan bahwa motivasi terdiri dari unsur internal dan eksternal. Unsur Internal individu berupa kebutuhan fisik maupun non fisik dan unsur eksternal antara lain seperti kebutuhan sosial, status, pengakuan, perhatian dan lainnya. Kebutuhan-kebutuhan tersebut secara naluriah, pasti seseorang berkeinginan menepuhnya dengan yang semudah-mudahnya, disinilah manfaat media digital atau informasi. Dikaitkan dengan motivasi peserta didik, unsur internal dapat memberikan motivasi untuk belajar. Motivasi ini terbentuk karena kesadaran diri atas pemahaman betapa pentingnya belajar untuk mengembangkan dirinya dan bekal untuk menjalani kehidupan masa depan. Selain itu faktor eksternal, yaitu dapat berupa rangsangan dari orang lain, atau lingkungan sekitarnya yang dapat memengaruhi psikologis orang yang bersangkutan, apakah itu dukungan pendidik, orang tua dan pengaruh kemajuan tehnologi digital.

Nur Maflikhah ( 2010 ), memberikan beberapa dimensi tentang kemanfaatan tehnologi informasi. Kemanfaatan dengan estimasi dua faktor dibagi menjadi dua kategori yaitu kemanfaatan dan efektvitas, dimensi kemanfaatan mempunyai fungsi : a. Menjadikan pekerjaan lebih mudah (makes job easter) 
b. Bermanfaat (useful).

c. Menambah produktivitas (increas productivity)

Efektifitas, berfungsi :

a. Mempertinggi efektifitas (encahance effectiveness ).

b. Pengembangan kinerja pekerja (inprove the job performance ) ${ }^{20}$

Pendapat Maflikhah memperjelas gambaran bahwa menggunakan tehnologi digital untuk memeperoleh informasi menumbumbuhkan kepercyaan bahwa pengguna tehnologi digital tersebut dapat berkontribusi positif bagi pengguna atau peserta didik. Dalam konteks pemanfaatan sistem informasi dan teknologi digital, kondisi yang memfasilitasi dapat dimasukkan sebagai salah satu faktor yang mempengaruhi pemanfaatan sistem informasi dan teknologi digital.Dalam penelitian yang dilakukan oleh Hj. Lindawati dan Irma Salamah Politeknik Negeri Sriwijaya dengan judul Pemanfaatan Sistem Informasi dan Teknologi Informasi Pengaruhnya Terhadap Kinerja Individual Karyawan, merujuk Penelitian yang dilakukan oleh Schultz dan Slevin (1975) dalam Sigalotang, Pontoh dan Syahrir (2006) membuktikan bahwa kondisi yang memfasilitasi pengguna sistem informasi dan teknologi informasi atau dukungan untuk pengguna sistem informasi dan teknologi informasi merupakan salah satu faktor yang mempengaruhi pemanfaatan sistem informasi dan teknologi informasi. Pontoh dan Syahrir (2006) terhadap bank di kota Makassar menunjukkan bahwa faktor kondisi yang memfasilitasi berpengaruh positif dan signifikan terhadap sistem informasi dan teknologi informasi. Sedangkan Irma (2012) menemukan bahwa kondisi yang memfasilitasi akan meningkatkan kinerja individual.

Penelitian yang dilakukan $H$. Lindawati maupun penelitian terdahulu objeknya lebih fokus kepada karyawan, kalaupun demikian, karena karyawan termasuk dalam rumpun Sumber Daya Manusia, maka dapat diidentikkan dengan peserta didik, sehingga tidaklah bersalahan jika hasil penelitian tersebut dijadikan rujukan dalam membahasa manfaat tehnologi digital terhadap motivasi belajar peserta didik, karena yang ditekankan samam-sama sisi manfaat dan meningkatkan aktivitas perilaku seseorang, oleh karena itu identik juga dengan peserta didik.

\footnotetext{
20 https// repository.unpas.ac.id (diakses 20 September 2017).
} 
Peserta didik merupakan gambaran kader pelanjut perjuangan 10 sampai 20 tahun mendatang, murid2 yang SD sekarang, 20 tahun lagi sudah menjadi dewasa dan bersolialisasi dengan masyarakat, dan memberikan gambaran bagaimana kualitas bangsa ini di mata dunia. Begiu juga yang di SMP, SLTA dan di Perguruan Tinggi, akan menjadi referensi bagaimana kita bisa mencari / mendapat bayangan kader bangsa yang akan datang.

Mempersiapkan Peserta didik menghadapi serta memanfaatkan tehnologi digital secara posistif merupakan kewajiban orang tua, Institusi pendidikan dan para pendidik. Jika revolusi digital dapat dimanfaatkan secara positif, maka akan dapat menjadi motivasi peserta didik untuk memhadapi tugas dan kewajibannya sebagai peserta didik. Sehingga motivasi dapat memberikan energi, usaha secara berkelanjutan dan dapat membantu pencapaian tujuan.

Kemajuan teknologi digital membawa orang ke dunia maya yang revolusioner, karena serba online, dirasakan lebih mudah, murah, praktis, dan dinamis dalam berkomunikasi dan memperoleh informasi.Seperti internet misalnya saat ini menjadi sebuah solusi untuk beberapa kalangan dan dalam kalangan pendidikan bermanfaat tehadap motivasi belajar peserta didik.Motivasi belajar tidak akan terbentuk apabila orang tersebut tidak mempunyai keinginan, cita-cita, atau menyadari manfaat belajar bagi dirinya. Oleh karena itu, dibutuhkan pengkondisian tertentu, agar diri kita atau siapa pun juga yang menginginkan semangat untuk belajar dapat termotivasi.Tips-tips untuk meningkatkan motivasi belajar peserta didik.Selain itu, coba cari orang atau komunitas yang mempunyai kebiasaan baik dalam belajar.Bertanyalah tentang pengalaman di berbagai tempat kepada orang-orang yang pernah atau sedang melanjutkan pendidikannya ke jenjang yang lebih tinggi. Kebiasaan mereka -mereka yang sudah sukses akan menular kepada kita, ibarat kata pepatah "alah bisa, menang biasa".

Berbicara tehnologi digital dapat dikatakan istilah lain dari tehnologi informasi, sehingga pendapat dal bidang ehnologi informasi dapat dijadikan rujukan dalam membahas manfaat tehnologi digital terhadap motivasi belajar peserta didik. Kaitannya dengan itu terdapat beberapa pendapat ahli yang dapat dijadikan rujukan antara lain pendapat Abdul Kadir (2014), mengemukakan bahwa tehnologi Informasi secara garis besar mempunyai peranan/ pentingnya sbb : 
1. Tehnologi informasi mengantikan peran manusia. Dalam hal ini tehnologi informasi melakukan otomatisasi terhadap suatu tugas atau proses.

2. Tehnologi Informasi memperkuat peran manusia, yakni dengan menyajikan informasi terhadap suatu tugas atau proses.

3. Tehnologi Informasi berperan dalam restrukturisasi tehadap peran perubahanperubahan terhadap sekumpulan tugas atau proses. ${ }^{21}$

Unsur -unsur dalam teori dan hasil penelitian yang dikemukakan diatas, sudah sangat jelas menunjukkan manfaat tehnologi digital bagi aktivitas manusia disegala aspek kehidupan, termasuk dibidang pendidikan. Proses pendidikan akan lebih mudah, praktis, efektif, efisien bagi kepentingan pendidik dan peserta didik. Pengembangan proses penyelenggaraan pendidikan, pengaruh revolusi tehnologi digital akan lebih modern, tergantung sekarang bagamana jajaran pendidikan membimbing peserta didik untuk memanfaatkan tehnologi digital dalam proses pembelajaran. Selain upaya -upaya untuk mengantisipasi bahaya atau ancaman yang mungkin ditimbulkan oleh pengaruh negatif dari revolusi digital yang berkembang sangat cepat. Sejalan dengan perkembangan tehnologi dan ilmu pengetahuan, lembaga pendidikan harus berani melakukan investasi dibidang tehnoligi didgital, minimal peserta didik terbantu untuk mengakses Internet bagi kepentingan pembelajaran. Alasan yang paling umum adalah adanya kebutuhan untuk mempertahankan dan meningkatkan posisi kompetitif, mengurangi biaya, meningkatkan fleksibilitas dan juga tanggapan. Terdapat banyakinstitusi pendidikan yang telah menerapkan tehnologi digital untuk mendukung berbagai aktivitas atau proses penyelenggaraan pendidikan. Hasil diperoleh pengaruh positif antaranyaadalah manfaat informasi bahan ajar dapat diperoleh dengan cepat, mudah, selanjutnya dapat mengolah, menyimpan dan mentransfer kembali, minimal ada hubungan timbal balik dalam proses pembelajaran antara pendidikan dan peserta didik.

Menurut Sutarman (2009), Pembelajaran saat ini banyak dilaksanakan dengan memanfaatkan media pembelajaran yang semakin canggih sebagai sumber belajar. Sumber belajar yang dimanfaatkan bukan hanya konvensional seperti perpustakaan,

${ }^{21}$ Ibid. https// repository.unpas.ac.id (diakses 20 September 2017). 
tetapi sumber belajar berbasis multimedia seperti internet telah banyak digunakan dan dikembangkan dalam dunia pendidikan. Melalui internet, siswa bisa mendapatkan informasi yang dibutuhkan dimanapun dan kapanpun waktu yang diinginkan. Sebagai sebuah sumber informasi yang hampir tak terbatas, maka jaringan internet dijadikan sebagai salah satu sumber pembelajaran. Disamping itu, perkembangan teknologi informasi yang sangat cepat dalam lingkungan kerja menyebabkan pemanfaatan teknologi informasi menjadi masalah yang mendesak..

Memperkuat analisis tentang manfaat tehnologi digital, kita rujuk Theory of Reasoned Action dari Fishbein dan Ajzen (1975) menyatakan bahwa perilaku seseorang adalah perkiraan dari intensitas dan tindakannya dimana seseorang akan menggunakan teknologi informasi jika hal itu bermanfaat dan meningkatkan kinerjanya dan begitu pula sebaiknya. Ficher (1996 dalam Silvia, 2001) menyatakan bahwa manfaat teknologi informasi baru dapat dirasakan jika pengguna teknologi informasi tersebut "menyadari" manfaatnya. Disamping itu, perkembangan teknologi informasi yang sangat cepat dalam lingkungan kerja menyebabkan pemanfaatan teknologi informasi menjadi masalah yang mendesak. ${ }^{22}$

Hasil pembahaan diatas meyakinkan kita bahwa pemanfaatan internet berpengaruh signifikan terhadap motivasi belajar pesert didik. Berdasarkan hasil analisis diatas lebih meyakinkan bahwa pemanfaatan tehnologi digital sebagai sarana belajar berpengaruh positif terhadap kemunculan motivasi belajar siswa sehingga diharapkan prestasi belajar siswa dapat tercapai secara optimal.Kehadiran sistem teknologi informasi telah banyak mengubah perilaku pendidik dan peserta didik. Saat ini proses penyelenggaraan pendidikan mulai bergantung pada sistem teknologi digital mulai dari pembelajaran dikelas, ataupun dalam menyelesaikan tugas-tugas, termasuk ujian akhir mulai menerapkan system digital. Dengan demikian, manfaat dan dampak langsung dari sistem teknologi digital ini terhadap individual pemakai dan yang kemudian akan meningkatkan motivasi belajar.

Dengan berkembangnya ilmu pengetahuan dan teknologi digital pada zaman sekarang ini, dikaitkan dengan proses pendidikan Indonesia sebagai Negara berkembang dituntut untuk mengikuti arus globalisasi dunia. Masyarakat Indonesia

22 http://karya-ilmiah.um.ac.id/index.php/akutansi/article/view/15922 (diakses Pada 25 September 2017 Jam 10.30 WITA) 
dihadapkan dengan berbagai fasilitas yang selalu berkembang. Salah satunya adalah perkembangan teknologi yang semakin mudah dijumpai. Perkembangan teknologi menghasilkan berbagai macam fasilitas, kualitas dan manfaat yang ditawarkan oleh teknologi digital, yang tujuannya untuk memudahkan segala aktivitas hidup manusia dalam melakukan pekerjaan dan mengakses berbagai informasi. Dengan adanya kemajuan teknologi ini, akan membawa pengaruh yang cukup besar terhadap segala aspek kehidupan, mulai dari kegiatan perkantoran, hiburan, keagamaan dan pendidikan.

Dalam segi dunia pendidikan kemajuan teknologi membawa manfaat yang sangat besar, baik dalam segi menyampaikan pelajaran untuk para pengajar dan pemahaman materi bagi peserta didik. Dibeberapa sekolah penggunaan media pembelajaran digital sudah menjadi sarana wajib bagi setiap sekolah. Adapun pengertian media pembelajaran digital adalah merupakan suatu jenis belajar mengajar yang memungkinan tersampaikannya bahan ajar ke siswa dengan menggunakan internet, dan media jaringan komputer lainnya. Sarana media pembelajaran digital yang bermutu dapat meningkatkan kualitas belajar siswa dan meningkatkan motivasi siswa dalam kegiatan belajar. Motivasi ini terbentuk karena kesadaran diri atas pemahaman betapa pentingnya belajar untuk mengembangkan dirinya dan bekal untuk menjalani kehidupan masa depan. Selain itu faktor eksternal, yaitu dapat berupa rangsangan dari orang lain, atau lingkungan sekitarnya yang dapat memengaruhi psikologis peserta didik yang bersangkutan.

Masalah pendidikan dari masa ke masa selalu menjadi perhatian. Kata para ahli "pendidikan adalah aset jangka panjang". Pendidikan menentukan nasib suatu bangsa. Berbagai macam cara dilakukan demi meningkatkan mutu pendidikan. Salah satu contoh adalah jepang. Mereka hancur pada saat perang dunia ke-2, namun sekarang mereka sangat maju dibanding dengan negara lain. Eric Ashby membagi Revolusi Pendidikan dalam 5 tahap.

1. Revolusi pertama Revolusi terjadi ketika orang menyerahkan pendidikan anaknya kepada seorang guru baik itu di padepokan, paguron, pesantren dan sekolah.

2. Revolusi kedua Revolusi terjadi ketika digunakannya tulisan untuk keperluan pembelajaran. Melalui tulisan ini dapat membuka akses yang sangat luas, sehingga informasi dapat disimpan dan dipanggil kembali. 
3. Revolusi ketiga Hal ini terjadi ketika mesin cetak ditemukan sehingga materi pembelajarandapat disajikan melalui media cetak, seperti buku teks, modul, majalah, dan lain-lain.

4. Revolusi keempat Revolusi ini terjadi ketika digunakannya perangkat elektronik dalam kegiatan pembelajaran, seperti radio, tape recorder, dan TV untuk pemerataan dan perluasan pendidikan.

5. Revolusi kelima Masa ini dimulai sejak digunakannya Teknologi Informasi dan Komunikasi ( TIK) dalam kegiatan pembelajaran, khususnya teknologi komputer dan internet untuk kepentingan peningkatan kegiatan pembelajaran. ${ }^{23}$

Persolannya sekarang apakah kita mengikuti tahap-tahap sebagaimana yang dilakukan Negara Jepang, menurut penulis Indonesia sekarang ini sudah berada pada repolusi digital tinggal bagaimana kecerdasan sumber daya pendidikan untuk memanfaatkan kemajuan tehnonologi digital sebagai motivasi peserta didik.

\section{Simpulan.}

Terdapat beberapa kecanggihan tehnologi digital seperti mudah bekerja karena beroperas secara otomatis, cepat, berkualitas, efektif, effisien, mudah mentransfer data dan informasi ke media elektronik lain. Dan banyak lagi kecanggihan-kecanggihan dari tehnologi digital ini yang dapat diambil manfaatnya untuk aktivitas manusia. Seperti Internet misalnya, kita bisa berhubungan secara online, sehingga manusia seolah-olah berada pada didunia yang sempit dengan jangkauan semakin luas, karena dirasakan lebih mudah, cepat dan dinamis menerima informasi serta berkomunikasi.

Kita harus cerdas memanfaatkan peluang kemajuan tehnologi digital, diberbagai bidang kehidupan termasuk dalam penyelenggaraan pendidikan. Peluang ini cukup memberikan harapan, jika dapat dimanfaatkan secara optimal, untuk meningkatkan motivasi belajar peserta didik dalam rangkaian meningkatkan kualitas pendidikan di Indonesia. Integrasi tehnologi digital dengan penyelenggaraan pendidikan, sudah terakit dalam sebuah jaringan yang cukup rapi, sekarang ini dikenal dalam dunia pendidikan istilah E-Learning yaitu belajar melalui dunia online, artinya

${ }^{23}$ Rusman, Deny Kurniawan, Cepi Riyana. Pembelajaran Berbasis TIK. 2011. Rajawali Press : Jakarta. 
peserta didik sudah dapat memanfaatkan tehnologi digital dalam belajar. Dengan demikian dapat disimpulkan manfaat tehnologi digital terhadap motivasi belajar peserta didik membuat cara belajar lebih baik.

\section{Daftar Pustaka.}

M. Burhan Bungin. 2001. Metodologi Penelitian Kualitatif, Penerbit Grapindo, Jakarta. Kuntari Eri Murti. 2013. Artikel Kurikulum pendidikan.

Stephen P. Robbins. 2010. Manajemen, Erlangga, Jakarta.

Sekretaris Negara Republik Indonesia, UU RI No:20 Tahun 2003, Tentang Sistem Pendidikan Nasional.

Tekno. Kompas.com (diakse 3 Agustus 2017).

http// sugikshare.blogspot.com ( diakses 20 September 2017)

Wikipedia bahasa Indonesia ( diakses 19 September 2017)

Wikipedia bahasa Indonesia ( di akses 29 September 2017).

http:/ /arifakbarmuhamad.wordpres.com ( diakses 2 Agustus 2017 ).

http://belajarpsikologi.com/pengertian-motivasi-belajar/

http://globallavebookx.blogspot.co.id/2015/03/pengertian-peserta-didik-menurutahli.html.

http://www.total.or.id( diakses 15 September 2017 ).

http://ajidedim.wordpress.com (diakses 19 September 2017)

http://ajidedim.wordpress.com (diakses 20 September 2017)

http://www.goechi.com (diakses 17 September 2017).

http://dictum4magz.wordpress.com/( diakses 20 September 2017 ).

http://dictum4magz. wordpress.com( diakses 20 September 2017 ).

winstarlink.com. apakah Indonesia sudah siap dg era digital (diakses 20 Agustus 2017 
https:// rostanto.blogspot.com (diakses 1 Agustus 2017).

https// repository.unpas.ac.id (diakses 20 September 2017)

https// repository.unpas.ac.id (diakses 20 September 2017)

http://karya-ilmiah.um.ac.id/index.php/akutansi/article/view/15922

Rusman,Deny Kurniawan, Cepi Riyana. Pembelajaran berbasis TIK. 2011. Rajawali Press : Jakarta 